\title{
The production of ornamental pineapple in pots under different drip-irrigation depths ${ }^{1}$
}

\author{
Márcio Davi Silva Santos ${ }^{2}$, Guilherme Vieira do Bomfim², Benito Moreira de Azevedo², \\ Ana Cristina Portugal Pinto de Carvalho ${ }^{3 *} \mathbb{D}$, Carlos Newdmar Vieira Fernandes ${ }^{4}$
}

$10.1590 / 0034-737 X 202067020003$

\begin{abstract}
The objective of this work was to evaluate the effects of irrigation depth on the commercial production of ornamental pineapple in pots. The experiment was carried out in a greenhouse located in Fortaleza, in the state of Ceará, Brazil. The experimental design was completely randomised, with five treatments and four replications. The treatments were irrigation depths estimated at 50,75,100,125, and $150 \%$ of the evapotranspiration of a crop of edible pineapple. The plants were grown in one litre pots, with supplementary irrigation every two days. The variables evaluated were: number of leaves; length and width of the ' $\mathrm{D}$ ' leaf; diameter of the rosette; plant height; rate of flowering; length and diameter of the peduncle, syncarp and crown; crown to syncarp ratio; commercial productivity and water-use efficiency. An increase in irrigation depth produced a linear increase in the number of leaves, width of the ' $\mathrm{D}$ ' leaf and rosette diameter, but had no effect on the other variables. Water-use efficiency decreased linearly with the increases in irrigation depth. Despite influencing leaf growth, each irrigation depth results in plants suitable for commercialisation in pots. The smallest irrigation depth gives the greatest economy and water-use efficiency.
\end{abstract}

Keywords: Ananas comosus var. erectifolius; ornamental plants; potted plants.

\section{INTRODUCTION}

The production chain for flowers and ornamental plants in Brazil is a branch of agribusiness with great potential for expansion in the global market (Junqueira \& Peetz, 2017). Among tropical ornamental plants commercialised both domestically and internationally, the ornamental pineapple is important. This importance can be explained by its exotic appearance, durability (Costa Junior $\mathrm{et} \mathrm{al}$., 2016; Lima et al., 2017) and use in the flower and foliage, landscaping and gardening, and potted-plant sectors (Souza etal., 2012;2014).

The most widely used variety of ornamental pineapple in agribusiness is Ananas comosus var. erectifolius. This variety is usually grown in the open to produce "cut flowers' (Souza et al., 2012). However, the growing global importance of the flower and potted-plant sector has created a promising market for the commercialisation of ornamental pineapple in pots (Pereira et al., 2018).

As this is a method of farming recently adopted by producers, there is little information on quantifying or managing the factors of production. Existing research, besides not being specific to the variety erectifolius, is basically concerned with genetic improvement (Taniguchi etal., 2015; Lima et al., 2017), mineral nutrition (Hawerroth et al., 2014; Viégas et al., 2014; Barbosa et al., 2015) and plant physiology (Reis et al., 2007; Mendes et al., 2011).

Information on irrigation, a topic which is relevant to the sustainability of the flower and ornamental-plant agribusiness (Junqueira \& Peetz, 2018), is practically nonexistent for ornamental pineapple grown in pots. As such, the crop is currently empirically and inadequately irrigated, using excessive water depths and frequencies (e.g. sprinkler irrigation with two daily one-hour pulses, as

\footnotetext{
Submitted on October $16^{\text {th }}, 2019$ and accepted on February $10^{\text {th }}, 2020$

${ }^{1}$ This work belongs to the Doctoral Thesis of the first author.

${ }^{2}$ Universidade Federal do Ceará, Departamento de Engenharia Agrícola, Fortaleza, Ceará, Brazil. marciodavy@yahoo.com.br; guile2007@gmail.com; benitoazevedo@hotmail.com

${ }^{3}$ Embrapa Agroindústria Tropical, Laboratório de Cultura de Tecidos e Genética Vegetal, Fortaleza, Ceará, Brazil. cristina.carvalho@embrapa.br

${ }^{4}$ Instituto Federal de Educação, Ciência e Tecnologia, Iguatu, Ceará, Brazil. newdmar@gmail.com

Corresponding author: cristina.carvalho@embrapa.br
} 
reported by the producers). Such management has increased the loss of water (drift and percolation) and nutrients (leaching), and the occurrence of phytosanitary problems.

Research on edible pineapple (Ananas comosus var. comosus) suggests that localised drip irrigation (Carr, 2012) and quantifying the water depth using climate parameters (Azevedo et al., 2007) are strategies that can help reduce water wastage and increase production potential.

Quantifying the irrigation depth for ornamental pineapple can be based on the water consumption of edible pineapple, since they are plants of the same species. However, as the ornamental variety is small and grown in a limited volume of substrate, it is important to adjust the amount of water through experimentation.

Therefore, considering the importance of the crop for agribusiness, and the lack of information on irrigation, the aim of this study was to evaluate the effects of different irrigation depths, which were estimated based on the water consumption of edible pineapple, on the commercial production of potted ornamental pineapple grown in a protected environment.

\section{MATERIAL AND METHODS}

The experiment was carried out in a greenhouse, between 16 July 2015 and 21 May 2016, in Fortaleza, in the

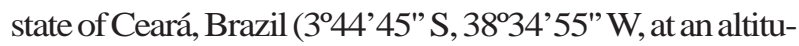
de of $19.5 \mathrm{~m}$ ).

The greenhouse had area of $76.8 \mathrm{~m}^{2}(12.0 \mathrm{~m} \times 6.4 \mathrm{~m})$, concrete floor, and ceiling and sides covered with antiaphid screen (mesh 50).

According to the Köppen climate classification, the region has a type Aw' climate, characterised as rainy tropical, tropical savanna, with the driest period during the winter and maximum rainfall during the summer-autumn.
During the experimental period, data for maximum and minimum air temperature, relative humidity, wind speed, rain and reference evapotranspiration were recorded using a digital weather station installed inside the greenhouse (Table 1).

The maximum and minimum air temperature, relative humidity and wind speed ranged from 32.6 to $30.6^{\circ} \mathrm{C}, 22.0$ to $19.8^{\circ} \mathrm{C}, 80.2$ to $68.5 \%$, and 4.2 to $3.1 \mathrm{~m} \mathrm{~s}^{-1}$ respectively. Rainfall was concentrated during the summer and autumn, and totalled $1,099.6 \mathrm{~mm}$. The reference evapotranspiration totalled $1,698.8 \mathrm{~mm}$.

The variety of ornamental pineapple used was Ananas comosus var. erectifolius. The micropropagated plants were acclimatised for two months (15 April 2015 to 16 June 2015) in $70 \%$ shade, and then transferred to the pots to be grown in a greenhouse.

Before transferring the plants to the greenhouse, the pots were filled with $\mathrm{HS}_{\mathrm{Slorestal}}{ }^{\circledR}$ substrate and fertilised with Osmocote ${ }^{\circledR}$ Plus 15-09-12 slow-release fertiliser. The black, cone-shaped plastic pots had an approximate volume of $1 \mathrm{~L}(13.9 \mathrm{~cm}$ wide, $11.6 \mathrm{~cm}$ high and $10.2 \mathrm{~cm}$ deep).

The HS Florestal ${ }^{\circledR}$ substrate, formulated with composted pine bark, vegetable peat and vermiculite, had a water retention capacity at a pressure of $10 \mathrm{~cm} \mathrm{H}_{2} \mathrm{O}$ (WRC) of $51.4 \%$, dry density of $290.2 \mathrm{~kg} \mathrm{~m}^{-3}$, organic C of $147.5 \mathrm{~g} \mathrm{~kg}^{-1}$, total $\mathrm{N}$ of $4.2 \mathrm{~g} \mathrm{~kg}^{-1}, \mathrm{C} / \mathrm{N}$ of $35.2, \mathrm{P}$ (Mehlich extractor) of $93.7 \mathrm{mg} \mathrm{L}^{-1}, \mathrm{~K}$ (Mehlich extractor) of $435.0 \mathrm{mg}$ $\mathrm{L}^{-1}$, Ca of $53.1 \mathrm{mg} \mathrm{L}^{-1}, \mathrm{Mg}$ of $238.0 \mathrm{mg} \mathrm{L}^{-1}$, CEC of 475.3 mmol $\mathrm{kg}^{-1}, \mathrm{pH}$ (in water) of 5.0, and EC of $0.9 \mathrm{dS} \mathrm{m}^{-1}$.

The Osmocote ${ }^{\circledR}$ Plus fertiliser, with three months longevity, presented $15.00 \% \mathrm{~N}, 9.00 \% \mathrm{P}, 12.00 \% \mathrm{~K}, 1.30 \%$ $\mathrm{Mg}, 5.90 \% \mathrm{~S}, 0.02 \% \mathrm{Bo}, 0.05 \% \mathrm{Cu}, 0.46 \% \mathrm{Fe}, 0.06 \% \mathrm{Mn}$, $0.02 \% \mathrm{Mo}$ and $0.05 \% \mathrm{Zn}$. The recommended amount of $13.9 \mathrm{~g}$ per pot (Hawerroth et al., 2014) was split into three applications after transplanting, based on the longevity of the fertiliser.

Table 1: Data for air temperature (T), relative humidity (RH), wind speed (WS), rainfall (R) and reference evapotranspiration (ETo) during the experiment with potted ornamental pineapple (Ananas comosus var. erectifolius) grown in a greenhouse with anti-aphid screen, in Fortaleza, Ceará, Brazil

\begin{tabular}{|c|c|c|c|c|c|c|c|c|}
\hline \multicolumn{3}{|c|}{ Date } & $\mathbf{T}_{\text {Max. }}\left({ }^{\circ} \mathrm{C}\right)$ & $\mathbf{T}_{\text {Min. }}\left({ }^{\circ} \mathbf{C}\right)$ & RH(\%) & $\mathbf{W S}\left(\mathrm{m} \mathrm{s}^{-1}\right)$ & $\mathbf{R}(\mathbf{m m})$ & ETo(mm) \\
\hline Month & Year & Day & \multicolumn{2}{|c|}{ Unit } & \multicolumn{2}{|c|}{ Mean } & \multicolumn{2}{|c|}{ Total } \\
\hline July & 2015 & 16 to 31 & 30.6 & 20.0 & 74.5 & 3.8 & 0.0 & 83.1 \\
\hline August & 2015 & 1 to 31 & 31.6 & 20.2 & 69.8 & 4.1 & 0.0 & 162.8 \\
\hline September & 2015 & 1 to 30 & 31.8 & 21.4 & 70.6 & 4.1 & 0.0 & 158.6 \\
\hline October & 2015 & 1 to 31 & 32.4 & 21.6 & 68.5 & 4.2 & 0.0 & 162.8 \\
\hline November & 2015 & 1 to 30 & 32.2 & 22.0 & 70.1 & 4.1 & 0.5 & 160.3 \\
\hline December & 2015 & 1 to 31 & 32.6 & 21.0 & 71.4 & 3.7 & 21.2 & 192.0 \\
\hline January & 2016 & 1 to 31 & 32.0 & 21.0 & 80.2 & 3.1 & 214.5 & 161.7 \\
\hline February & 2016 & 1 to 29 & 32.4 & 19.8 & 79.9 & 3.2 & 255.6 & 154.2 \\
\hline March & 2016 & 1 to 31 & 32.4 & 21.0 & 78.0 & 3.4 & 123.4 & 172.9 \\
\hline April & 2016 & 1 to 30 & 32.6 & 21.0 & 79.0 & 3.2 & 338.1 & 163.7 \\
\hline May & 2016 & 1 to 21 & 32.0 & 21.6 & 75.8 & 3.4 & 146.3 & 126.6 \\
\hline
\end{tabular}

Rev. Ceres, Viçosa, v. 67, n.2, p. 111-118, mar/apr, 2020 
After distributing the pots over the surface of the greenhouse (at a spacing of $15 \mathrm{~cm} \times 15 \mathrm{~cm}$ ), a surface dripirrigation system was installed, comprising a water reservoir, pumpunit, main line of $\operatorname{PVC}(\phi=20 \mathrm{~mm})$, submain and lateral lines of LDPE $(\phi=16 \mathrm{~mm})$, stopcocks, a glycerine-filled pressure gauge, disc filter and compensating drippers, which were placed near the plant roots using microtubes. The irrigation system was evaluated using the methodology by Keller \& Karmeli (1974). The coefficient of distribution uniformity (CDU) and the mean flow rate of the emitters were estimated at $93 \%$ and $3.2 \mathrm{Lh}^{-1}$.

The water used for irrigation showed a $\mathrm{Ca}, \mathrm{Mg}, \mathrm{Na}, \mathrm{K}$, $\mathrm{Cl}_{\text {and }} \mathrm{HCO}_{3}$ content of 1.0, 1.7, 4.3, 0.2, 3.8 and $3.6 \mathrm{mmol}$ $\mathrm{L}^{-1}$; EC of $0.73 \mathrm{dS} \mathrm{m}^{-1}$; SAR of 3.81 ; $\mathrm{pH}$ of 7.9 and $\mathrm{a} \mathrm{C}_{2} \mathrm{~S}_{1}$ classification (Ayers \& Westcot, 1985).

The first irrigation was carried out to increase the substrate moisture to field capacity and reduce the stress of transplanting the plants to the pots. Transplanting was carried out on 16 June 2015 in the late afternoon, to reduce climate stress. The plants were irrigated daily with $0.15 \mathrm{~L}$ of water for one month to favour their adaptation to the growth environment. After this period, on 16 July 2015, the different treatments were introduced.

The experimental design was completely randomised, with five treatments, four replications and four plants per plot. The treatments consisted of irrigation depths, estimated at $50,75,100,125$ and $150 \%$ of the crop evapotranspiration for edible pineapple.

Crop evapotranspiration was estimated from Equation 1.

$\mathrm{Etc}=\mathrm{ETo} \times \mathrm{Kc}$

where: $\mathrm{ETc}=$ crop evapotranspiration for edible pineapple $\left(\mathrm{mm} \mathrm{day}^{-1}\right) ; \mathrm{ETo}=$ reference evapotranspiration $\left(\mathrm{mm} \mathrm{day}^{-1}\right)$; $\mathrm{Kc}=$ crop coefficient for edible pineapple (dimensionless).

The ETo was estimated using the Penman-Monteith methodology (Allen et al., 2006). The Kc varied according to the phenological phases of the crop: 0.6 during phase I (1-60 days), from 0.6 to 1.2 during phase II (61-210 days), 1.2 during phase III (211-270 days), and from 1.2 to 0.6 during phase IV (271-360 days) (Almeida, 1995). In the differing treatments, the Kc was interpolated from 0.7 to 1.2 during phase II (120 days), 1.2 during phase III (90 days) and from 1.2 to 0.6 during phase IV (102 days).

Supplementary irrigation was carried out as per Equation 2.

$\mathrm{Id}=\mathrm{ETc}-\mathrm{Pe}$

where: Id = irrigation depth $\left(\mathrm{mm} \mathrm{day}^{-1}\right) ; \mathrm{ETc}=$ crop evapotranspiration for edible pineapple $\left(\mathrm{mm} \mathrm{day}^{-1}\right) ; \mathrm{Pe}=$ effective precipitation or rainfall $\left(\mathrm{mm} \mathrm{day}^{-1}\right)$.
The Id, accumulated over a two-day interval, was only applied when the ETc was greater than the Pe. Pe was considered to be any rainfall of less than $9.8 \mathrm{~mm}$. Theoretically, this would be the greatest water depth captured by a pot with an area of $0.0154 \mathrm{~m}^{2}$ and retained by a substrate with a mean mass of $0.29 \mathrm{~kg}$ and WRC of $51.4 \%$. When the Pe was greater than the ETc, it was not accumulated in the following irrigation. The Id was applied considering a water application efficiency of $93 \%$.

The ETc, Pe and Id were quantified during phenological stages II, III and IV, with the aim of evaluating the pattern of the demand and availability of water for the crop throughout the experimental phase.

The individual volumes of rainfall and irrigation were quantified every two days and compared graphically with the maximum volume of water retained by the substrate (field or pot capacity), to evaluate possible water loss through percolation and the risk of nutrient loss through leaching for each treatment. The water content at field capacity, considering a mass and WRC for the substrate of $0.29 \mathrm{~kg}$ and $51.4 \%$, was estimated at $0.15 \mathrm{~L}$.

Crop treatments were carried out weekly and consisted of cleaning the greenhouse, the manual removal of dry leaves and tillers, and floral induction.

Floral induction was carried out nine months after transplanting (16 March 2016) using an ethephon-based solution. The solution was prepared with $1 \mathrm{~L}$ of water, 0.45 mL of Ethre ${ }^{\circledR}$ (0.324 $\mathrm{g}$ of ethephon), $0.35 \mathrm{~g}$ of calcium hydroxide and $20 \mathrm{~g}$ of urea. Each plant received $30 \mathrm{~mL}$ of the solution, which was manually applied to the apical bud region using a plastic cup. In most plants, the formation of the flower buds occurred 35 days after floral induction (20 April 2016), the fruit being formed 30 days later(20 May 2016).

The principal stages of the experiment can be seen in Figure 1.

After formation of the fruit, characterised by the closing of the last flower (21 May 2015), the following variables were evaluated: number of leaves; length and width of the ' $\mathrm{D}$ ' leaf; diameter of the rosette; plant height; rate of flowering; length and diameter of the peduncle, syncarp and crown; crown to syncarp ratio; and commercial productivity.

All the plants in each plot were used to measure leaf number, length and width of the ' $\mathrm{D}$ ' leaf, rosette diameter, and plant height, as well as to estimate flowering rate and commercial productivity. To measure the other variables, two flower stems per plot were used.

The number of leaves was counted manually for each plant. The length of the ' $D$ ' leaf was measured from the stem insertion to the leaf apex. The width of the ' $D$ ' leaf was measured from one edge of the leaf to the other at the widest point. The diameter of the rosette was measured in 
opposite directions between the apices of two leaves. Plant height was measured from the root collar to the apex of the highest leaf. All measurements were made with the aid of a tape measure.

The rate of flowering was estimated from the ratio between the number of plants with an infructescence and the total number of plants. The length of the peduncle was measured from its insertion in the leaves to the base of the syncarp. The diameter of the peduncle was measured at half its height. The length of the syncarp and crown were measured by the distance between their poles. The diameter of the syncarp and crown were measured in the central region. The crown to syncarp ratio was estimated by dividing their lengths. All measurements were made with the aid of a digital calliper.

Commercial productivity was calculated as the product of the percentage of commercial plants and the number of plants that would fit into a greenhouse of $360 \mathrm{~m}^{2}$. The percentage of commercial plants was estimated as the ratio between the number of commercial plants and the total number of plants. Commercial plants were considered those that presented no aesthetic problems in the leaves or flower stems (deformity, wilting, discolouration, chlorosis, necrosis or spots) and those that fit into the category for use in pots: height $<65.0 \mathrm{~cm}$, diameter of the rosette $<80.0$ $\mathrm{cm}$, length of the ' $\mathrm{D}$ ' leaf $<60.0 \mathrm{~cm}$, length and diameter of the syncarp $<5.0$ and $3.0 \mathrm{~cm}$, length of the peduncle and crown $<30.0$ and $5.0 \mathrm{~cm}$, and a crown to syncarp ratio of up to 1.5 (Souza et al., 2007; 2012). The number of plants, considering cultivation in double rows of $0.6 \mathrm{~m}$ x $0.3 \mathrm{~m} \mathrm{x}$ $0.3 \mathrm{~m}$, was estimated at 1056 units.

Water-use efficiency was calculated from Equation 3.

$\mathrm{WUE}=\frac{\mathrm{Y}}{\mathrm{W}}$

where: WUE $=$ water-use efficiency (number of plants L$\left.{ }^{1}\right)$; $\mathrm{Y}=$ number of commercial plants that would fit into a greenhouse of $360 \mathrm{~m}^{2}$ (dimensionless); $\mathrm{W}=$ total water depth for the crop cycle (L).
The mean data for the response variables were submitted to regression analysis, considering the linear and quadratic models. Model selection was based on the significance $(\mathrm{P}<0.5)$ of the models (F-test) and the coefficients of the equations (t-test), the coefficient of determination $\left(\mathrm{R}^{2}\right)$, and appropriateness of the model to the biological phenomenon.

\section{RESULTS AND DISCUSSION}

\section{Water demand and availability during the experimental phase}

Water demand and availability during phenological phases II, III and IV of the ornamental pineapple is shown in Table 2.

The estimated evapotranspiration for ornamental pineapple showed an increase of $0.32 \%$ between phases II and III, and a reduction of $14.1 \%$ between phases III and $\mathrm{IV}$, due to the presence of rainfall mitigating the climate conditions.

Because of the lack of rainfall, irrigation during phase II was fully carried out. During this period, each plant was irrigated with a total volume of water of 4.6, 6.9, 9.2, 11.5 and $13.9 \mathrm{~L}$, as per the 50, 75, 100, 125 and $150 \%$ ETc treatments respectively. Irrigation during phases III and IV was supplementary, as the effective rainfall during both periods gave a respective total of 2.7 and $3.6 \mathrm{~L}$ of water per plant. The volume of water from irrigation totalled 3.3, 5.2, 7.2, 9.3 and 11.4 L per plant during phase III, and 2.5, 4.0, 5.6, 7.2, and 9.0 L per plant during phase IV, in line with the $50,75,100,125$ and $150 \%$ ETc treatments.

Throughout the experimental period (phenological phases II to IV), each plant received 16.7, 22.4, 28.3, 34.3 and $40.5 \mathrm{~L}$ of water from the effective rainfall and the irrigation, as per the 50, 75, 100, 125 and $150 \%$ ETc treatments.

The individual volumes of rainfall and irrigation during the phenological phases II, III and IV of the ornamental pineapple are shown in Figure 2.

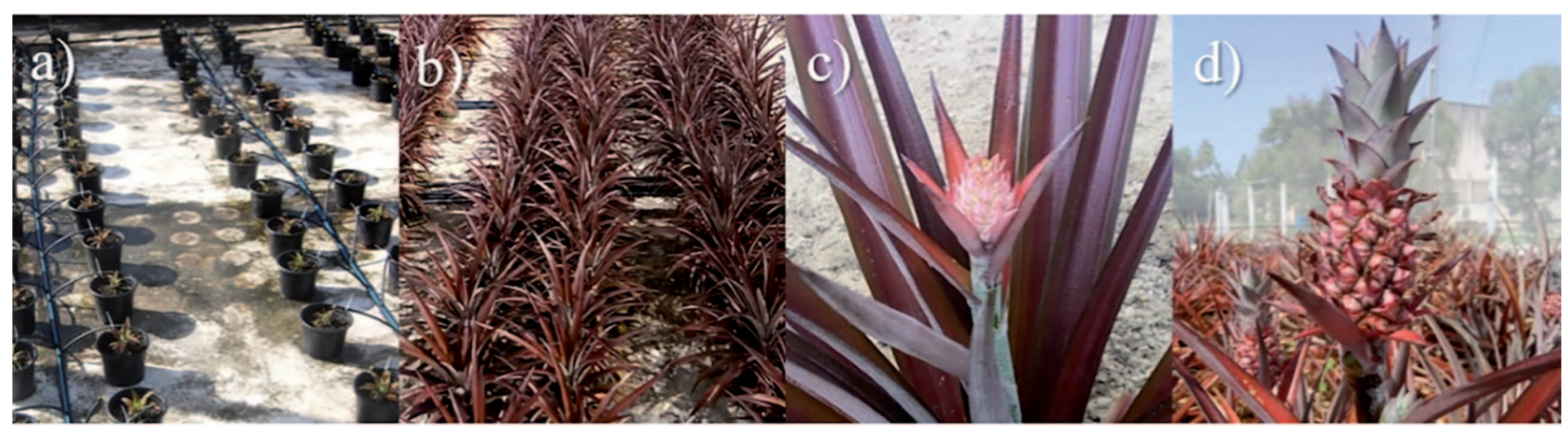

Figure 1: Adaptation (a), leaf growth (b), floral initiation (c) and formation of the infructescence (d) in ornamental pineapple (Ananas comosus var. erectifolius) grown in pots during the experiment carried out in a greenhouse with anti-aphid screen (16 July 2015 to 21 May 2016), in Fortaleza, Ceará, Brazil.

Rev. Ceres, Viçosa, v. 67, n.2, p. 111-118, mar/apr, 2020 
In the 50 and $75 \%$ ETc treatments, the volumes of irrigated water were close to the maximum waterretention limit of the substrate throughout the experimental period.

In the $100 \%$ ETc treatment, and particularly the 125 and $150 \%$ ETc treatments, the volume of irrigated water exceeded the pot capacity throughout almost the entire experimental phase. In these treatments, the largest respective water volumes reached 158.1, 197.6, and $237.1 \%$ of pot capacity. This means that the irrigation based on these treatments caused a loss of water and nutrients due to excessive drainage; however, nutrient loss was probably minimised by the slow-release fertiliser.

Irrigation at water depths greater than field capacity are only justified if they result in an increase in production. If not, in addition to wastage, they may increase the leaching of nutrients such as $\mathrm{N}$ and K (Jia et al., 2014; Mendes et al., 2016). Leaching may be a necessary strategy to reduce excessive salts in the root zone. However, the amount of water used should be minimal to save water resources and avoid environmental contamination (Kisekka etal., 2019).

\section{Vegetative growth in the ornamental pineapple}

A summary of the regression analysis for the vegetative growth variables of the ornamental pineapple is shown in Table 3.

The length of the ' $\mathrm{D}$ ' leaf and plant height did not respond to the water depth. The ' $\mathrm{D}$ ' leaf showed a minimum and maximum length of 34.5 and $54.0 \mathrm{~cm}$, with a mean value of $44.9 \pm 2.1 \mathrm{~cm}$. The plants displayed a minimum and maximum height of 40.5 and $68.0 \mathrm{~cm}$, with a mean of $55.4 \pm$ $3.5 \mathrm{~cm}$.

The number of leaves, width of the ' $\mathrm{D}$ ' leaf and diameter of the rosette responded to the water depth. The increasing linear regression model fit the data (Figure 3 ).

The minimum, maximum and mean values for number of leaves per plant, width of the ' $\mathrm{D}$ ' leaf and diameter of the rosette were estimated at 39.1, 50.3, and 44.7 units; 2.1 , 3.1 and $2.6 \mathrm{~cm}$; and 57.6, 79.5 and $67.1 \mathrm{~cm}$ respectively. The percentage increase in the $75,100,125$ and $150 \%$ ETc treatments compared to the $50 \%$ ETc treatment was, on average, $7.2,14.4,21.6$ and $28.8 \%$ for the number of leaves (Figure 3a); 11.5, 23.1, 34.6 and $46.1 \%$ for the width of the 'D' leaf(Figure 3b); and 8.2, 16.4, 24.5 and $37.2 \%$ for the diameter of the rosette (Figure $3 \mathrm{c}$ ).

Table 2: Water demand and availability during the phenological phases of ornamental pineapple (Ananas comosus var. erectifolius) grown in pots, during the experiment carried out in a greenhouse with anti-aphid screen (16 July 2015 to 21 May 2016), in Fortaleza, Ceará, Brazil

\begin{tabular}{|c|c|c|c|c|c|c|c|c|c|}
\hline \multirow{2}{*}{ Treatment } & \multicolumn{3}{|c|}{ Phase II (90 days) } & \multicolumn{3}{|c|}{ Phase III (120 days) } & \multicolumn{3}{|c|}{ Phase IV (102 days) } \\
\hline & ETc & Pe & $\mathbf{I d}$ & ETc & $\mathbf{P e}$ & Id & ETc & $\mathbf{P e}$ & $\mathbf{d}$ \\
\hline \multicolumn{10}{|l|}{$\mathbf{m m}$} \\
\hline $50 \% \mathrm{ETc}$ & 299.8 & 0.0 & 299.8 & 300.8 & 173.0 & 214.2 & 258.3 & 236.0 & 157.9 \\
\hline $75 \%$ ETc & 449.7 & & 449.7 & 451.1 & & 336.7 & 387.5 & & 251 \\
\hline $100 \% \mathrm{ETc}$ & 599.6 & & 599.6 & 601.5 & & 466.7 & 516.6 & & 350.7 \\
\hline $125 \% \mathrm{ETc}$ & 749.5 & & 749.5 & 751.9 & & 601 & 645.8 & & 453.1 \\
\hline $150 \%$ ETc & 899.4 & & 899.4 & 902.3 & & 739.4 & 774.9 & & 560.7 \\
\hline
\end{tabular}

ETc - crop evapotranspiration for edible pineapple; Pe - effective rainfall; Id - irrigation depth.

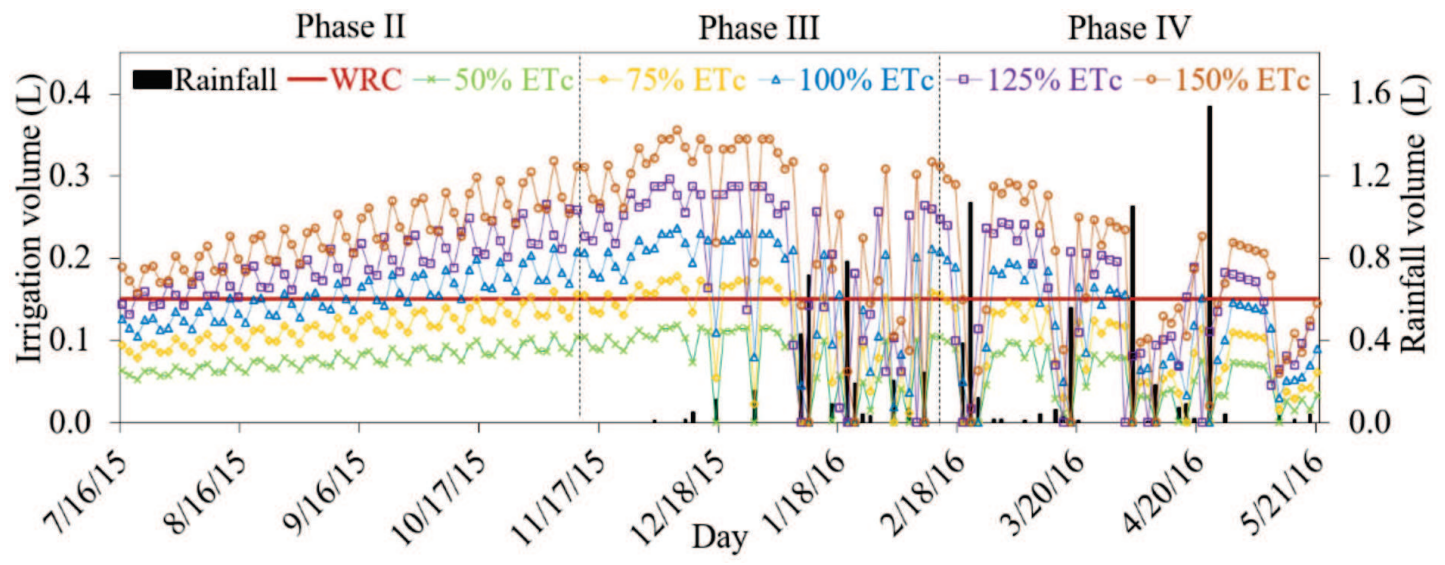

Figure 2: Rainfall and irrigation volumes during the phenological phases of ornamental pineapple (Ananas comosus var. erectifolius) during an experiment in a greenhouse with anti-aphid screen, in Fortaleza, Ceará, Brazil. ETc - crop evapotranspiration for edible pineapple; WRC - water retention capacity. 
The plants showed no aesthetic problems on the leaves for any of the water depths under test, and were classified for use in pots, since the length of the ' $\mathrm{D}$ ' leaf, diameter of the rosette and plant height were less than 60.0, 80.0 and $65.0 \mathrm{~cm}$ respectively (Souza et al., 2012).

Considering that the potted-plant market is seeking increasingly compact products, it can be inferred that the smallest water depths gave the best results. In this context, irrigating at $50 \%$ ETc was the most beneficial, as it resulted in more-compact plants (Figure 3), with greater savings in water resources (Figure 2).

The satisfactory growth of the ornamental pineapple at the smallest water depths can be explained by the size and metabolism of the crop and the occurrence of rainfall. The size of the ornamental variety, a function of genetics and the restrictive conditions of pot cultivation, is smaller than that of the variety used (edible pineapple) in calculating the irrigation.

Small plants, due to their reduced leaf area, require less water (Tan et al., 2015). In addition, the crassulacean acid metabolism (CAM) allows nocturnal $\mathrm{CO}_{2}$ fixation, increasing water-use efficiency and facilitating adaptation to low water-availability (Zhang et al., 2014). The rainfall during phase III and IV may also have reduced the effect of the smallest water depths on leaf morphology.

\section{Reproductive growth and water-use efficiency in the ornamental pineapple}

The summary of the regression analysis indicates that the reproductive growth variables were not influenced by the water depth (Table 4).

The minimum, maximum and mean rates of flowering were 75,100 and $95 \pm 4.8 \%$ respectively. Considering the confidence interval of the mean, the rate of flowering for all treatments can vary from 90.2 to $99.8 \%$. Flowering rates greater than $90 \%$ are usually seen in artificial induction of the edible pineapple using an ethephon-based solution (Cunha, 2005).

The sensitivity of the crop to floral induction depends on plant maturity in terms of size and chronological age (Cunha, 2005; Poel et al., 2009). Therefore, as the length of the 'D' leaf, one of the principal parameters indicating

Table 3: Summary of the regression analysis for the vegetative growth variables of ornamental pineapple (Ananas comosus var. erectifolius) grown in pots in a greenhouse with anti-aphid screen, in Fortaleza, Ceará, Brazil

\begin{tabular}{lccccc}
\hline \multirow{2}{*}{ Regression } & \multicolumn{5}{c}{ F-test $(\mathbf{P}<\mathbf{0 . 0 5})$} \\
\cline { 2 - 6 } & $\mathbf{N}$ & $\mathbf{I L}$ & $\mathbf{I W}$ & $\mathbf{D R}$ & HH \\
\hline Linearmodel & $18.4^{*}$ & $0.9^{\text {ns }}$ & $84.8^{*}$ & $20.2^{*}$ & $3.0^{\text {ns }}$ \\
Quadratic model & $0.3^{\text {ns }}$ & $0.2^{\text {ns }}$ & $6.7^{*}$ & $0.3^{\text {ns }}$ & $4.5^{\text {ns }}$ \\
\hline CV $(\%)$ & 9.3 & 10.9 & 6.3 & 9.9 & 11.8
\end{tabular}

* significant; ${ }^{\text {ns }}$ not significant; NL - number of leaves; LL - length of the 'D' leaf; LW - width of the 'D' leaf; DR - diameter of the rosette; $\mathrm{PH}$ - plant height.

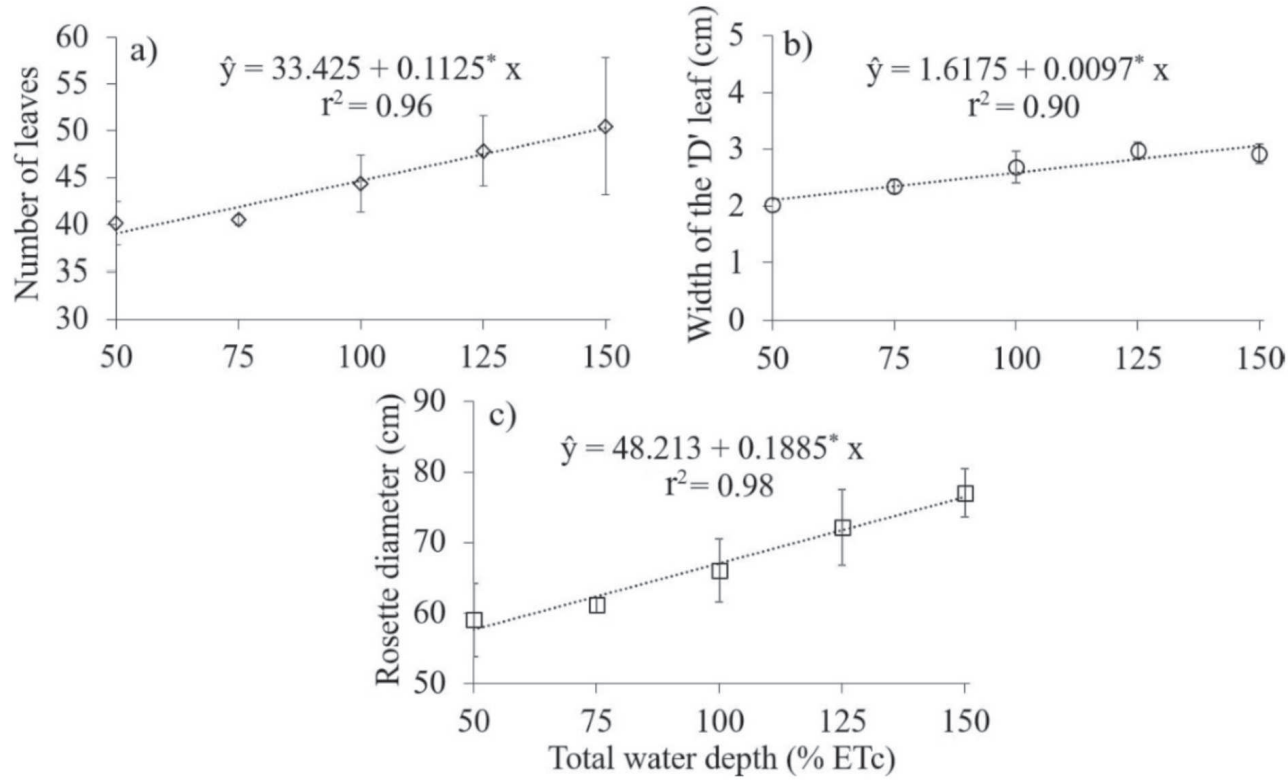

Figure 3: Linear increase in the number of leaves (a), width of the ' $D$ ' leaf (b) and rosette diameter (c) in potted ornamental pineapple (Ananas comosus var. erectifolius), with the increase in total water depth estimated from five percentages of the crop evapotranspiration $(\mathrm{ETc})$ for edible pineapple. " significant by t-test $(\mathrm{P}<0.05)$. 
Table 4: Summary of the regression analysis for the reproductive growth variables and water-use efficiency of ornamental pineapple (Ananas comosus var. erectifolius) grown in pots in a greenhouse with anti-aphid screen, in Fortaleza, Ceará, Brazil

\begin{tabular}{lcccccccccc}
\hline \multirow{2}{*}{ Regression } & \multicolumn{10}{c}{ F-test $(\mathbf{P}<\mathbf{0 . 0 5})$} \\
\cline { 2 - 11 } & $\mathbf{R F}$ & LP & DP & LS & DS & LC & DC & LC/LS & CP & WUE \\
\hline Linear model & $2.4^{\text {ns }}$ & $0.9^{\text {ns }}$ & $2.9^{\text {ns }}$ & $1.1^{\text {ns }}$ & $1.9^{\text {ns }}$ & $1.3^{\text {ns }}$ & $3.3^{\text {ns }}$ & $0.8^{\text {ns }}$ & $0.7^{\text {ns }}$ & $285.3^{*}$ \\
Quadratic model & $0.4^{\text {ns }}$ & $2.6^{\text {ns }}$ & $1.0^{\text {ns }}$ & $1.4^{\text {ns }}$ & $3.1^{\text {ns }}$ & $1.0^{\text {ns }}$ & $0.6^{\text {ns }}$ & $0.4^{\text {ns }}$ & $0.0^{\text {ns }}$ & $18.0^{*}$ \\
\hline CV $(\%)$ & 10.7 & 22.8 & 18.8 & 14.5 & 8.1 & 28.8 & 32.4 & 23.4 & 10.1 & 8.8 \\
\hline
\end{tabular}

" significant; ${ }^{\text {ns }}$ not significant; RF - rate of flowering; LP and DP - length and diameter of the peduncle; LS and DS - length and diameter of the syncarp; LC and DC - length and diameter of the crown; LC / LS - ratio between the length of the crown and length of the syncarp; CP - commercial productivity; WUE - water-use efficiency.

maturity (Poel et al., 2009), also showed no response to the water depths under test, it can be assumed that the maturity of the plants was similar. This would explain the high rate of flowering in each treatment.

In some plants, failing (delay) to flower may have been the result of ethephon efficiency, which can be affected by biotic factors (cuticle, trichome, etc.) and abiotic factors (temperature, humidity, etc.) (Cunha, 2005).

In relation to the flower stem, the peduncle presented a minimum, maximum and mean value of 10,25 and $17 \pm$ $1.9 \mathrm{~cm}$ in length, and $0.8,1.5$ and $1.1 \pm 0.1 \mathrm{~cm}$ in diameter respectively. The minimum, maximum and mean values for the length and diameter of the syncarp were 2.5, 4.7 and $3.75 \pm 0.3 \mathrm{~cm}$, and $2.2,3.0$ and $2.70 \pm 0.1 \mathrm{~cm}$ respectively. The crown had a minimum, maximum and mean value of 2.2,5.0 and $4.2 \pm 0.5 \mathrm{~cm}$ for length, and 1.7, 6.2 and $3.1 \pm 0.7$ $\mathrm{cm}$ for diameter. The ratio between the length of the crown and syncarp length had a minimum, maximum and mean value of $0.7,1.5$ and $1.1 \pm 0.1$.

At each of the irrigation depths under test, the plants showed no aesthetic problems in the flower stem, and were classified for use in pots, as they had a syncarp length and diameter of less than 5.0 and $3.0 \mathrm{~cm}$, crown length and diameter of less than 30.0 and $5.0 \mathrm{~cm}$, and a crown to syncarp ratio of up to 1.5 (Souza et al., 2007; 2012).

Commercial productivity in the ornamental pineapple was similar to the flowering rate, since the plants showed no problems in the appearance or dimensions of the leaves or flower stems for each water depth under test. The minimum, maximum and mean values were estimated at 792,1056 and $1016 \pm 50$ plants per greenhouse respectively.

Increasing the water depth reduced water-use efficiency (Figure 4).

Water-use efficiency was maximised with $50 \% \mathrm{ETc}$. The percentage decrease of the 75, 100, 125 and $150 \%$ ETc treatments compared to the $50 \%$ ETc treatment, was estimated with the linear model to be 18.8,37.6, 56.4 and $75.2 \%$ in that order. In addition to the greater economy of water resources, supplementary irrigation with $50 \% \mathrm{ETc}$, resulted in plants with a more compact leaf architecture. This characteristic is important, since one of the main criteria for the visual quality of potted ornamental plants

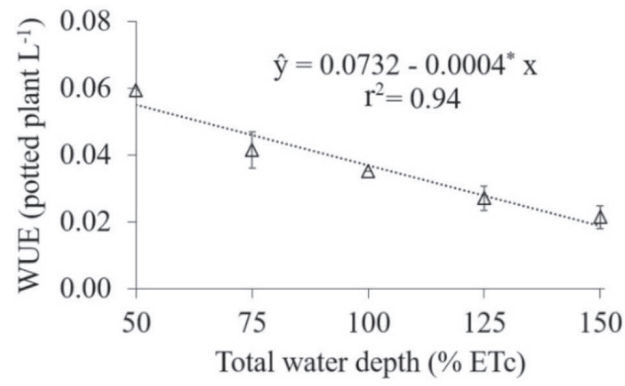

Figure 4: Linear reduction in the water-use efficiency (WUE) of ornamental pineapple (Ananas comosus var. erectifolius) in pots, for an increase in total water depth estimated from five percentages of the crop evapotranspiration (ETc) for edible pineapple. ${ }^{*}$ significant by t-test $(\mathrm{P}<0.05)$.

is the shape, which should be compact and well-branched (Ferrante et al., 2015).

According to the results, it can be inferred that it is more advantageous to drip-irrigate ornamental pineapple every two days with half the water depth estimated for edible pineapple, in this case, with $1,087.6 \mathrm{~mm}$ or $16.7 \mathrm{~L}$ of water per plant during the experimental period (310 days). In terms of irrigation management, this means that the water demand of the crop could be calculated at values for Kc of from 0.35 to 0.60 during phase II (120 days), from 0.60 during phase III ( 90 days), and from 0.60 to 0.30 during phase IV (102 days) respectively.

\section{CONCLUSIONS}

Supplementary drip-irrigation at water depths between 50 and $150 \%$ of the ETc of edible pineapple influences leaf growth only in ornamental pineapple grown in pots in a greenhouse with anti-aphid screen.

An increase in water depth causes a linear increase in the number of leaves, the width of the ' $\mathrm{D}$ ' leaf and diameter of the rosette. Despite differences in leaf growth, each water depth gave vigorous plants with no problems of appearance, and with the vegetative and reproductive dimensions required for commercialisation in pots.

The replacement depth estimated with half the ETc of edible pineapple results in the greatest water-use economy and efficiency.

Rev. Ceres, Viçosa, v. 67, n.2, p. 111-118, mar/apr, 2020 


\section{ACKNOWLEDGEMENTS, FINANCIAL SUPPORT AND FULL DISCLOSURE}

The authors wish to thank CAPES for their financial help, UFC for conceding the experimental area and infrastructure, and EMBRAPA for providing the inputs and scientific support.

The authors declare there to be no conflict of interest in carrying out or publishing this work.

\section{REFERENCES}

Allen RG, Pereira LS, Raes D \& Smith M (2006) Evapotranspiración del cultivo: guías para la determinación de los requerimientos de agua de los cultivos. Roma, FAO. 300p.

Almeida AO (1995) Irrigação em abacaxi. Cruz das Almas, EMBRAPA CNPMF. 33p.

Ayers RS \& Westcot DW (1985) Water quality for agriculture. Rome, FAO. 174p.

Azevedo PV, Souza CB, Silva BB \& Silva VPR (2007) Water requirements of pineapple crop grown in a tropical environment, Brazil. Agricultural Water Management, 88:201-208.

Barbosa TMB, Santos JZL, Tucci CAF, Silva SV, Cardoso AAS \& Pereira BFF (2015) Phosphorus sources: effects on growth and phosphorus fractions of Curauá (Ananas erectifolius L. B. Smith). Communications in Soil Science and Plant Analysis, 46:12001211.

Carr MKV (2012) The water relations and irrigation requirements of pineapple (Ananas comosus var. comosus): a review. Experimental Agriculture, 48:488-501.

Costa Junior DS, Souza EH, Costa MAPC, Pereira MEC \& Souza FVD (2016) Clonal evaluation of new ornamental pineapple hybrids to use as cut flowers. Acta Scientiarum Agronomy, 38:475483 .

Cunha GAP (2005) Applied aspects of pineapple flowering. Bragantia, 64:499-516

Ferrante A, Trivellini A, Scuderi D, Romano D \& Vernieri P (2015) Post-production physiology and handling of ornamental potted plants. Postharvest Biology and Technology, 100:99-108.

Hawerroth FJ, Mauta DS, Cândido MS, Taniguchi CAK, Hawerroth MC \& Serrano LAL (2014) Adubo de liberação lenta na produção de abacaxizeiro ornamental em vaso. Fortaleza, Embrapa Agroindústria Tropical. 19p.

Jia X, Shao L, Liu P, Zhao B, Gu L, Dong S, Zhang J \& Zhao B (2014) Effect of different nitrogen and irrigation treatments on yield and nitrate leaching of summer maize (Zea mays L.) under lysimeter conditions. Agricultural Water Management, 137:92-103.

Junqueira AH \& Peetz MS (2017) Intellectual property rights in Brazilian floriculture: innovations for the growth and development of the market. Ornamental Horticulture, 23:296306 .

Junqueira AH \& Peetz MS (2018) Sustainability in Brazilian floriculture: introductory notes to a systemic approach. Ornamental Horticulture, 24:155-162.

Keller J \& Karmeli D (1974) Trickle irrigation design parameters. Transactions of the ASAE, 17:678-684.

Kisekka I, Kandelous MM, Sanden B \& Hopmans JW (2019) Uncertainties in leaching assessment in micro-irrigated fields using water balance approach. Agricultural Water Management, 213:107-115
Lima OS, Souza EH, Dias LEC, Souza CPF \& Souza FVD (2017) Characterization and selection of ornamental pineapple hybrids with emphasis on sinuous stems and black fruits. Pesquisa Agropecuária Tropical, 47:237-245.

Mendes BSS, Willadino L, Cunha PC, Oliveira Filho RA \& Camara TR (2011) Mecanismo fisiológicos e bioquímicos do abacaxi ornamental sob estresse salino. Revista Caatinga, 24:71-77.

Mendes WC, Alves Júnior J, Cunha PCR, Silva AR, Evangelista AWP \& Casaroli D (2016) Potassium leaching in different soils as a function of irrigation depths. Revista Brasileira de Engenharia Agrícola e Ambiental, 20:972-977.

Pereira GND, Souza EH, Souza JS \& Souza FVD (2018) Public perception and acceptance of ornamental pineapple hybrids. Horticultura Ornamental, 24:116-124.

Poel BV, Ceusters J \& Proft MP (2009) Determination of pineapple (Ananas comosus, MD-2 hybrid cultivar) plant maturity, the efficiency of flowering induction agents and the use of activated carbon. Scientia Horticulturae, 120:58-63.

Reis INRS, Santos Filho BG, Castro CVB, Lameira CN \& Rossato V (2007) Trocas gasosas e alocação de biomassa em plantas jovens de Curauá (Ananas erectifolius L. B. Smith) submetidas ao alagamento. Revista Brasileira de Biociências, 5:507-509.

Souza EH, Souza FVD, Costa MAPC, Costa Júnior DS, SantosSerejo JA, Amorim EP \& Ledo CAS (2012) Genetic variation of the Ananas genus with ornamental potential. Genetic Resources and Crop Evolution, 59:1357-1376.

Souza EH, Costa MAPC, Santos-Serejo JA \& Souza FVD (2014) Selection and use recommendation in hybrids of ornamental pineapple. Revista Ciência Agronômica, 45:409-416.

Souza FVD, Cabral JRS, Souza EH, Santos OSN, Santos-Serejo JA \& Ferreira FR (2007) Caracterização morfológica de abacaxizeiros ornamentais. Magistra, 19:319-325.

Tan CL, Wong NH, Tan PY, Jusuf SK \& Chiam ZQ (2015) Impact of plant evapotranspiration rate and shrub albedo on temperature reduction in the tropical outdoor environment. Building and Environment, 94:206-217.

Taniguchi CAK, Castro ACR, Silva TF \& Café FBS (2015) Development of pineapple as an ornamental potted plant. Acta Horticulturae, 1087:379-384.

Viégas IJM, Silva RNP, Silva DAS, Oliveira Neto CF, Conceição HEO, Mascarenhas GS, Okumura RS, Monfort LEF \& Silva RTL (2014) Mineral composition and visual symptoms of nutrients deficiencies in Curauá plants (Ananas comosus var. erectifolius). Australian Journal of Crop Science, 8:747-753.

Zhang J, Liu J \& Ming R (2014) Genomic analyses of the CAM plant pineapple. Journal of Experimental Botany, 65:01-10.

Rev. Ceres, Viçosa, v. 67, n.2, p. 111-118, mar/apr, 2020 